\title{
Myocardial Excitation-contraction Coupling in the Fetus of Alloxan-diabetic Rabbit
}

\author{
TOSHIO NAKANISHI, SUGURU MATSUOKA, SHIGERU UEMURA, TATSUO SHIMIZU, \\ KENYA NISHIOKA, NAOMI D. NEUFELD, AND JAY M. JARMAKANI \\ Department of Pediatrics, Division of Cardiology, University of California, Los Angeles Medical Center, \\ Los Angeles, California 90024
}

\begin{abstract}
This study was conducted to investigate myocardial excitation-contraction coupling in the fetus of the diabetic rabbit (FDM). On day 14 of gestation, diabetes was induced in pregnant rabbits by alloxan injection. On day 28 of gestation, mechanical function of the fetal myocardium was determined in the isolated arterially perfused heart preparation. At $1.5 \mathrm{mM}\left[\mathrm{Ca}^{2+}\right]_{o}$ (control), the force of myocardial contraction in FDM was not significantly dfferent from that in the control fetus. At higher $\left[\mathrm{Ca}^{2+}\right]_{\text {o, }}$ developed tension and maximal rate of tension development [+dT/dt $(\max )]$ in FDM were significantly greater than in the control fetus. High $\left[\mathrm{Ca}^{2+}\right]_{o}$ caused significant increases in resting tension and half-relaxation time (toxic effects) in the control fetus, but not in FDM. Perfusion with lanthanum (known to displace sarcolemma-bound $\mathrm{Ca}^{2+}$ and block sarcolemmal $\mathrm{Na}$-Ca exchange) decreased developed tension and $+\mathrm{dT} / \mathrm{dt}(\max )$ and increased resting tension and these effects in FDM were significantly less than in the control fetus. Perfusion with manganese (known to displace $\mathrm{Ca}^{2+}$ from intracellular sites) also decreased developed tension and $+\mathrm{dT} / \mathrm{dt}(\max )$ and increased resting tension, and these effects were similar in the two groups. The myofibrillar ATPase activities at various calcium concentrations were not different between the two groups. The rates of $\mathrm{Ca}^{2+}$ uptake by mitochondria and sarcoplasmic reticulum were similar in the two groups. These data suggest that in FDM the inotropic effect of $\mathrm{Ca}^{2+}$ is greater and the toxic effect of $\mathrm{Ca}^{2+}$ is less than in the control fetus. This difference may be due, at least in part, to a sarcolemmal alteration induced by the maternal diabetes. (Pediatr Res 18:1344-1349, 1984)
\end{abstract}

\section{Abbreviations}

DT, developed tension

RT, resting tension

$+\mathrm{dT} / \mathrm{dt}$ (max), maximal rate of tension development

$-\mathrm{dT} / \mathrm{dt}(\mathrm{max})$, maximal rate of relaxation

TPT, time to peak tension

$1 / 2 \mathbf{R T}$, half-time to relaxation

HEPES, 4-(2-hydroxyethyl)-1-piperazineethanesulfonic acid

FDM, fetus of diabetic rabbit

TES, $\quad N$-tris(hydroxymethyl)methyl-2-aminoethanesulfonic acid

Received November 4, 1983; accepted June 22, 1984.

Address reprint requests to Jay M. Jarmakani, M.D., UCLA Medical Center, 10833 Le Conte Avenue, Los Angeles, CA 90024.

This work was supported by Research Grant HL-24148 from the National Heart, Blood, and Lung Institute and Investigative Group Fellowship Award 506IG8 from the American Heart Association, Greater Los Angeles Affiliate.
DTT, dithiothreitol

SR, sarcoplasmic reticulum

EGTA, ethylene glycol bis( $\beta$-aminoethyl ether)-

$N, N, N^{\prime}, N^{\prime}$-tetraacetic acid

E-C, excitation-contraction

In newborns of diabetic mothers, cardiac abnormalities such as hypertrophic cardiomyopathy, left ventricular outflow obstruction, and congestive heart failure may occur (8). Hyperinsulinemia, hyperglycemia, and other alterations in carbohydrate, lipid, and protein metabolism occur in the fetus of the diabetic mother $(3,12,22,23)$. These abnormal metabolisms may alter normal development of the fetal myocardium. However, there has been no information about the effect of maternal diabetes on the contractile function of the fetal myocardium. This study was designed to investigate myocardial mechanical function and the function of myocardial subcellular organelles in the fetus of the diabetic mother. Because it is difficult to assess muscle function per se in in vivo study, we used the isolated heart preparation. Diabetes was induced in the pregnant rabbit and mechanical function of the isolated fetal heart was studied using various interventions which are known to alter $\mathrm{Ca}^{2+}$ availability to the excitation-contraction coupling elements (i.e. extracellular space, sarcolemma, and intracellular organelles).

\section{MATERIALS AND METHODS}

Induction of Diabetes Mellitus. Diabetes mellitus was induced in pregnant rabbits as described previously (17). We did not induce diabetes before pregnancy because the conception rate in the diabetic rabbits was low. Pregnant New Zealand White rabbits were utilized in pairs. One rabbit of the pair received alloxan (Sigma; $80 \mathrm{mg} / \mathrm{kg}$ body weight) in sterile $0.9 \% \mathrm{NaCl}$ solution intravenously on day 14 of pregnancy (term, 31 days). Alloxan injection at this time is known to cause minimal disturbance of fetal pancreatic endocrine function (1). During the $24 \mathrm{~h}$ following the alloxan injection, the rabbit received $10 \%$ dextrose in water for drinking. The other rabbit of the pair, which served as a control, received intravenous saline without alloxan. Blood samples were taken for glucose determination immediately preceding and at 2-3-day intervals following alloxan injection. To minimize the effect of malnutrition which might be associated with severe diabetes, diabetic animals with moderate hyperglycemia $(140-220 \mathrm{mg} / \mathrm{dl})$ were utilized in the present study. The daily food intake of the diabetic animals was similar to that of the control animals.

On day 28 of gestation, the fetuses were delivered by cesarean section after sacrificing the doe with intravenous pentobarbital 
sodium $(50 \mathrm{mg} / \mathrm{kg})$. The fetuses were immediately transferred to a warm, humidified couveuse and kept at $37^{\circ} \mathrm{C}$ until the initiation of the experiments. All experiments were started within 5 min after birth. The fetuses were heparinized $(0.15$ unit/g body weight $)$ and anesthetized with sodium pentobarbital $(0.05 \mathrm{mg} / \mathrm{g}$ body weight intraperitoneally). The heart was then excised from the chest cavity and used for either mechanical function study or biochemical determination. Since pentobarbital may depress cardiac function, care was taken to excise the hearts as soon as the animals were anesthetized. In a preliminary study, baseline mechanical function of the fetus, which was killed by pentobarbital injection, was not significantly different from that of the fetus killed by decapitation. Maternal and pooled fetal blood was saved for subsequent determination of glucose and insulin concentrations (17).

Experimental Preparation for Mechanical Function Study. Experiments were performed in the isolated, arterially perfused ventricular preparation (Langendorf preparation) as described previously (10). Although the papillary muscle preparation may be more desirable for mechanical function study, the Langendorf preparation was used in the present study in order to perform mechanical function study and biochemical study in the same tissue (16). After the heart was excised, the aorta was cannulated with a PE50 polyethylene cannula and was secured with a silk suture. The heart was perfused with oxygenated perfusate at a constant perfusion rate of $2.5 \mathrm{ml} / \mathrm{g}$ tissue/min using a Harvard pump. The base of the right and left ventricles was fixed between the two Harmon forceps and the apex was attached to the Statham transducer using a silk suture. The muscle was stimulated with $4-\mathrm{V}, 10-\mathrm{ms}$ duration pulses at a rate of $36 / \mathrm{min}$, and its temperature was maintained at $27 \pm 0.5^{\circ} \mathrm{C}$. Under these conditions, myocardial mechanical function, high energy phosphate, and electrolyte contents $\left(\mathrm{K}^{+}\right.$and $\left.\mathrm{Ca}^{2+}\right)$ have been shown to remain stable for $5 \mathrm{~h}(10,15)$. Additional experiments were performed at a myocardial temperature of $37^{\circ} \mathrm{C}$. Under these conditions, mechanical function was less stable than at $27^{\circ} \mathrm{C}$. Tension was measured using a force transducer and a bridge amplifier (Accudata 113, Honeywell). The first derivative of tension with respect to time was derived using an analog differentiator (Accudata 132). The following parameters of mechanical function were monitored with a Brush 220 recorder (Gould): DT, RT, +dT/dt (max), -dT/dt (max), TPT, and 1/2RT. TPT was defined as the time from the onset to the peak of developed tension, and $1 / 2 \mathrm{RT}$ as the time required for tension to fall to $50 \%$ of the maximal value.

Perfusion Solutions. The control Krebs-Henseleit solution contained (mM): $\mathrm{NaCl}, 118 ; \mathrm{KCl}, 6 ; \mathrm{CaCl}_{2}, 1.5 ;$ glucose, $6 ; \mathrm{MgCl}_{2}$, 1; $\mathrm{NaHCO}_{3}, 24 ;$ and $\mathrm{NaH}_{2} \mathrm{PO}_{4}, 0.436$. The solutions were equilibrated with $95 \% \mathrm{O}_{2}$ and $5 \% \mathrm{CO}_{2}$ yielding a final $\mathrm{pH}, \mathrm{PCO}_{2}$, and $\mathrm{O}_{2}$ content of $7.3-7.4,35-42 \mathrm{~mm} \mathrm{Hg}$, and 1.9-2.2 volume \%, respectively.

The control HEPES solution contained (mM): $\mathrm{NaCl}, 133$, $\mathrm{KCl}, 6 ; \mathrm{CaCl}_{2}, 1.5, \mathrm{MgCl}_{2}, 1.0$, glucose, 6; HEPES, 3.0. This solution was bubbled with $100 \% \mathrm{O}_{2}$ and the $\mathrm{pH}$ was adjusted to 7.4 with $0.1 \mathrm{~N} \mathrm{NaOH}$. Lanthanum $\left(\mathrm{La}^{3+}, 5 \mu \mathrm{M}\right)$ or manganese $\left(\mathrm{Mn}^{2+}, 0.5 \mathrm{mM}\right)$ was added to the control HEPES solution.

Experimental Protocol. Initially, the muscles were perfused with a control solution containing $1.5 \mathrm{mM}$ calcium for $60 \mathrm{~min}$ to allow for stabilizaton of mechanical function. During the initial $40 \mathrm{~min}$ of each experiment, the length of the muscle preparation was adjusted so that the tension was equal to $90 \%$ of maximal tension. After this initial period, both resting tension and length-tension relationship remained unchanged under control conditions. The following studies were then performed.

Calcium and Mechanical Function. The muscles were perfused with Krebs-Henseleit solutions containing 0.10, 0.30, 0.75, 3.0, $7.5,10,15,20,30$, and $40 \mathrm{mM} \mathrm{Ca}^{2+}$. Since bicarbonate decreases the percentage of ionized calcium in the solution (10), all solutions used were filtered and the ionized calcium was determined using a Ca-selective electrode (Beckman). The ionized calcium varied from 87 to $92 \%$ of total $\mathrm{Ca}^{2+}$ in the various solutions. To eliminate intergroup differences in calcium solubility, the studies in the normal fetus and the fetus of the diabetic mother were performed using the same solutions. The duration of perfusion was $5 \mathrm{~min}$ at each calcium concentration. Mechanical function reached a new steady state 2 min after switching to a new calcium concentration, and all measurements were made at $4 \mathrm{~min}$. $\mathrm{Pa}$ rameters describing mechanical function were expressed as a percentage of control values and a g/g tissue wet weight. Since the muscle preparation was not cylindrical, we expressed DT and $+\mathrm{dT} / \mathrm{dt}(\max )$ as $\mathrm{g} / \mathrm{g}$ tissue and not as $\mathrm{g} /$ cross-sectional area. The geometry and length of the muscle preparation were similar in FDM and normal fetus.

Because the osmolarity of solutions containing high calcium content increased, the effect of high osmolarity per se was determined in additional experiments; $22.5,45$, and $90 \mathrm{mM}$ mannitol was added to the control solution to equalize osmolarity with that of $7.5,15$, and $30 \mathrm{mM}$ calcium solutions, respectively. The muscles were perfused with solutions containing mannitol for 30 min, and mechanical function reached a new steady state within 20 min of perfusion.

$\mathrm{La}^{3+}$ and $\mathrm{Mn}^{2+}$. Because $\mathrm{La}^{3+}$ precipitates out of a bicarbonate buffer solution, the effect of uncouplers $\left(\mathrm{La}^{3+}\right.$ and $\left.\mathrm{Mn}^{2+}\right)$ on excitation-contraction was studied using the HEPES solution. $\mathrm{La}^{3+}$ displaces $\mathrm{Ca}^{2+}$ bound to the sarcolemma (2) and blocks sarcolemmal Na-Ca exchange (21), but it does not permeate the plasma membrane (6). $\mathrm{Mn}^{2+}$ enters the cells and displaces $\mathrm{Ca}^{2+}$ from intracellular sites (19). After 60 -min stabilization of mechanical function with a control HEPES solution, the muscle was perfused for $20 \mathrm{~min}$ with a HEPES solution containing either $5 \mu \mathrm{M} \mathrm{LA}^{3+}$ or $0.5 \mathrm{mM} \mathrm{Mn}^{2+}$. These concentrations of uncouplers have been shown to cause significant depression of myocardial mechanical function in the newborn and adult rabbit (7).

Biochemical Studies. Mitochondrial isolation. Eight to 10 ventricles of the fetuses were utilized for mitochondrial isolation, which was carried out at $0-4^{\circ} \mathrm{C}$ as described previously (16). Approximately $1.3 \mathrm{~g}$ of muscle was minced and homogenized in 14 volumes of the isolation solution containing $180 \mathrm{mM} \mathrm{KCl}$, $10 \mathrm{mM}$ EDTA, $5 \mathrm{mM}$ Tris- $\mathrm{HCl}$, and $0.5 \%$ bovine serum albumin $(\mathrm{pH} 7.1)$. The homogenate was centrifuged at $500 \times g$ for 10 min. The supernatant was centrifuged at $10,000 \times g$ for 10 min and the resulting mitochondrial pellet was washed three times.

Isolation of sarcoplasmic reticulum. SR was isolated using a modified method of Jones et al. (11) as described previously (16). Twelve to 20 fetal hearts derived from two pregnant rabbits were pooled and utilized for SR isolation. Approximately $2 \mathrm{~g}$ of the muscle was minced and homogenized in 4 volumes of the isolation solution containing $10 \mathrm{mM} \mathrm{NaHCO}_{3}(\mathrm{pH} \mathrm{7.1)}$. The homogenate was centrifuged at $1000 \times g$ for $10 \mathrm{~min}$. The resulting pellet was utilized for myofibrillar isolation. The supernatant was centrifuged three times at $14,000 \times g$ for $20 \mathrm{~min}$. The supernatant from the third spin was centrifuged at 45,000 $\times g$ for $30 \mathrm{~min}$. The pellet was suspended in a solution containing $0.6 \mathrm{M} \mathrm{KCl}$ and $10 \mathrm{mM}$ TES (pH 7.1) using a glass-Teflon homogenizer. The suspension was centrifuged at $45,000 \mathrm{~g}$ for 30 min. The resulting pellet was then suspended in a small volume of solution containing $150 \mathrm{mM} \mathrm{KCl}$ and $1 \mathrm{mM}$ TES (pH 7.1).

Myofibrillar isolation. The myofibrillar fraction was isolated by a modified method of Solaro et al. (25) as described previously (16). The first pellet of the sarcoplasmic reticulum isolation was washed four times with a solution containing $60 \mathrm{mM} \mathrm{KCl}, 10$ mM TES, DTT ( $\mathrm{pH} 7.1$ ). The resulting pellet was washed two times in a solution containing $60 \mathrm{mM} \mathrm{KCl}, 10 \mathrm{mM}$ TES, $1 \mathrm{mM}$ DTT, and $1 \%$ Triton $\mathrm{X}-100(\mathrm{pH} \mathrm{7.1)}$. The resulting pellet was then suspended in a solution containing $60 \mathrm{mM} \mathrm{KCl}, 10 \mathrm{mM}$ TES, $1 \mathrm{mM}$ DTT, and $2 \mathrm{mM}$ EDTA (pH 7.1) and washed four times.

Assay of $\mathrm{Ca}^{2+}$ uptake. $\mathrm{Ca}^{2+}$ uptakes by mitochondria and SR were determined at $27^{\circ} \mathrm{C}$ using the Millipore filtration method and a scintillation counter as described previously (16). A desired 
$\mathrm{Ca}^{2+}$ concentration in the medium was obtained using an EGTA buffer system (4).

Ca uptake by mitochondria was determined in medium I containing $30 \mathrm{mM}$ TES, $1 \mathrm{mM} \mathrm{K}$-EGTA, $2 \mathrm{mM} \mathrm{K}_{2} \mathrm{HPO}_{4}, 5$ $\mathrm{mM} \mathrm{K}_{2}$ succinate, $112 \mathrm{mM} \mathrm{KCl}$, and $0.983 \mathrm{mM} \mathrm{CaCl}_{2}\left({ }^{45} \mathrm{Ca}\right)$ (pH 7.1 with $\mathrm{KOH}$ ). Because $\mathrm{Mg}^{2+}$ inhibits respiration-dependent $\mathrm{Ca}^{2+}$ uptake and intracellular $\mathrm{Mg}^{2+}$ concentration remains uncertain, $\mathrm{Mg}^{2+}$ was eliminated from the solution in some experiments. When $\mathrm{Mg}^{2+}$ was added, the free $\mathrm{Mg}^{2+}$ concentration was $3.16 \mathrm{mM}$. Ca uptake by SR was determined in medium II containing $30 \mathrm{mM}$ TES, $1 \mathrm{mM} \mathrm{K}_{2}$-EGTA, $5 \mathrm{mM} \mathrm{K}_{2}$ oxalate, $3.25 \mathrm{mM} \mathrm{Na}$-ATP, $9 \mathrm{mM} \mathrm{MgCl}$, $5 \mathrm{mM}$ azide, $106 \mathrm{mM} \mathrm{KCl}$, and $1.009 \mathrm{mM} \mathrm{CaCl}_{2}\left({ }^{45} \mathrm{Ca}\right)(\mathrm{pH} 7.1$ with $\mathrm{KOH})$. Free $\mathrm{Ca}^{2+}$ concentration in media I and II was $10^{-5}$ (pCa 5). Reaction was started by the addition of $20 \mu \mathrm{g}$ of SR protein or $100 \mu \mathrm{g}$ of mitochondrial protein to $1 \mathrm{ml}$ of the preincubated reaction medium (a preincubation time of $3 \mathrm{~min}$ ). After incubation at $27^{\circ} \mathrm{C}$ for selected periods $(15 \mathrm{~s}, 30 \mathrm{~s}, 1 \mathrm{~min}, 5 \mathrm{~min}, 15 \mathrm{~min}$, and $30 \mathrm{~min}$ ), the suspension was placed on a Millipore filter (HA $0.45 \mu \mathrm{M}$ ). The filter was then suspended in Aquasol (New England Nuclear) and the radioactivity of ${ }^{45} \mathrm{Ca}$ was measured by a liquid scintillation counter.

Protein was measured by the Lowry method (14) using bovine serum albumin as a standard.

Assay of $\mathrm{Ca}^{2+}-$ ATPase activity. $\mathrm{Ca}^{2+}$-ATPase activity in the SR fraction was measured at $27^{\circ} \mathrm{C}$ in reaction medium II described above. $\mathrm{Ca}^{2+}$-ATPase activity was calculated by subtracting the ATPase activity in the presence of $1 \mathrm{mM}$ EGTA (no added $\mathrm{Ca}$ ) from the activity in the presence of $1 \mathrm{mM}$ EGTA and $1.009 \mathrm{mM} \mathrm{CaCl}_{2}$ added (pCa 5).

Myofibrillar ATPase activity was measured at $27^{\circ} \mathrm{C}$ and at low ionic strength $(0.0758 \mathrm{M})$ using a modified method of Solaro et al. (24). The reaction medium contained $30 \mathrm{mM}$ TES, $1 \mathrm{mM}$ $\mathrm{K}_{2}$-EGTA, $3.58 \mathrm{mM} \mathrm{Na}_{2}$-ATP, $6.8 \mathrm{mM} \mathrm{MgCl}_{2}$ (free $\mathrm{Mg}^{2+}=3.16$ $\mathrm{mM}), 5 \mathrm{mM}$ azide, $47 \mathrm{mM} \mathrm{KCl}$, and various amounts of $\mathrm{CaCl}_{2}$ (pH 7.1 with $\mathrm{KOH}$ ). The reaction was started by the addition of enzymes and stopped by the addition of $0.5 \mathrm{ml}$ of ice-cold $20 \%$ trichloroacetic acid. Inorganic phosphate concentration in the medium was then measured using the method of Fiske and Subbarow (5).

Assay of marker enzymes. $\left(\mathrm{Na}^{+}-\mathrm{K}^{+}\right)$-ATPase activity (a sarcolemmal marker) and cytochrome $c$ oxidase activity (mitochondrial marker enzyme) were measured using methods of Bers and Langer (2), and Wharton and Tzagoloff (28), respectively.

Statistical Analysis. Results are expressed as the mean \pm SE. Statistical analysis was performed using the two-tailed $t$ test for paired and unpaired data (27). Per cent changes were compared using nonparametric methods (Wilcoxon's signed rank test or Wilcoxon's rank sum test) (27). The probability was considered to be significant if the $p$ value was less than 0.05 .

\section{RESULTS}

Maternal glucose levels in the alloxan-treated groups $(178 \pm 7$ $\mathrm{mg} / \mathrm{dl})$ was significantly $(p<0.01)$ greater than in the control group $(90 \pm 7)$. Maternal insulin in the control group was $9 \pm 1$ $\mu \mathrm{U} / \mathrm{ml}$ and that in the alloxan-treated group was undetectable by the radioimmunoassay method (the lower limit of insulin detectable being $4 \mu \mathrm{U} / \mathrm{ml}$ ). Fetal body weight, heart weight, and heart/body weight ratio were not significantly different in the two groups (Table 1). Serum glucose and insulin levels in the fetus of an alloxan-treated mother were significantly greater than in the control fetus.

Mechanical Function. Baseline data in the control fetus and FDM are shown in Table 2. All parameters of mechanical function under control conditions were similar in the two groups. The dimensions (approximately $4 \mathrm{~mm}$ in diameter and $8 \mathrm{~mm}$ in length), shape, and size of the heart were similar in the two groups.

Effect of $\left[\mathrm{Ca}^{2+}\right]$. The results of a typical experiment are shown
Table 1. Characteristics of fetal rabbits*

\begin{tabular}{lcc}
\hline & Normal fetus & FDM \\
\hline Heart wet wt $(\mathrm{g})$ & $0.136 \pm 0.005$ & $0.144 \pm 0.007$ \\
& $(19)$ & $(18)$ \\
Body wt $(\mathrm{g})$ & $29.6 \pm 0.9$ & $29.4 \pm 0.9$ \\
& $(19)$ & $(18)$ \\
Heart/body wt $\left(\times 10^{-3}\right)$ & $4.60 \pm 0.16$ & $4.90 \pm 0.14$ \\
& $(19)$ & $(18)$ \\
Serum glucose $(\mathrm{mg} / \mathrm{dl})$ & $47 \pm 2$ & $119 \pm 13 \dagger$ \\
& $(6)$ & $(6)$ \\
Serum insulin $(\mu \mathrm{U} / \mathrm{ml})$ & $22.3 \pm 2.2$ & $65.2 \pm 7.1 \dagger$ \\
& $(6)$ & $(6)$
\end{tabular}

* Values are means \pm SE. $n$, numbers of determination in parentheses. $\dagger p<0.01$.

in Figure 1. Figure 2 shows DT expressed as $\mathrm{g} / \mathrm{g}$ wet weight at various extracellular $\mathrm{Ca}^{2+}$ concentrations. At physiological $\mathrm{Ca}^{2+}$ concentrations, DT was similar in the two groups. In FDM, however, DT at $\left[\mathrm{Ca}^{2+}\right]_{\text {, }}$ higher than $1.5 \mathrm{mM}$ was significantly $(p$ $<0.001$ ) greater than in the control fetus. In FDM, $+\mathrm{dT} / \mathrm{dt}$ $(\max )$ at all $\left[\mathrm{Ca}^{2+}\right]_{o}$ except for $1.5 \mathrm{mM}$ was significantly $(p<$ $0.05)$ greater than in the control fetus. In both groups $+\mathrm{dT} / \mathrm{dt}$ (max) reached its maximal value at $15 \mathrm{mM}\left[\mathrm{Ca}^{2+}\right]_{0}$ and decreased at higher $\left[\mathrm{Ca}^{2+}\right]_{0}$.

In the control fetus, RT increased significantly $(p<0.001)$ at $30 \mathrm{mM}\left[\mathrm{Ca}^{2+}\right]_{\text {o }}$ (to $234 \pm 32 \%$ of control). In FDM, RT did not increase significantly at all $\left[\mathrm{Ca}^{2+}\right]_{\text {o }}$ values studied (Fig. 1). In the control fetus, $1 / 2 \mathrm{RT}$ increased significantly at $\left[\mathrm{Ca}^{2+}\right]_{\%}$ higher than $1.5 \mathrm{mM}(107 \pm 4 \%$ of control at $3 \mathrm{mM}, 112 \pm 2 \%$ at $7.5 \mathrm{mM}$, $115 \pm 3 \%$ at $15 \mathrm{mM}$, and $132 \pm 4 \%$ at $30 \mathrm{mM}$ ). In FDM, $1 / 2 \mathrm{RT}$ did not change significantly at all $\left[\mathrm{Ca}^{2+}\right]_{o}$ values studied. In the two age groups, both $\mathrm{RT}$ and $1 / 2 \mathrm{RT}$ at $\left[\mathrm{Ca}^{2+}\right]_{o}$ less than $1.5 \mathrm{mM}$ were similar to those at $1.5 \mathrm{mM}\left[\mathrm{Ca}^{2+}\right]_{0}$.

In experiments maintained at $37^{\circ} \mathrm{C}$, the absolute values of $+\mathrm{dT} / \mathrm{dt}(\max )$ were significantly greater than values obtained at $27^{\circ} \mathrm{C}$ but the effect of high $\left[\mathrm{Ca}^{2+}\right]_{0}$ mechanical function was directionally identical to that observed at $27^{\circ} \mathrm{C}$.

Osmolarity. Perfusion with solutions containing 22.5 and 45 $\mathrm{mM}$ mannitol did not alter mechanical function. Perfusion with $90 \mathrm{mM}$ mannitol (osmolarity equal to $30 \mathrm{mM} \mathrm{CaCl}_{2}$ ) increased DT and +dT/dt (max) significantly but did not change RT, TPT, and $1 / 2 \mathrm{RT}$. The increase in $+\mathrm{dT} / \mathrm{dt}(\max )$ in FDM $(5.3 \pm 1.4 \mathrm{~g} /$ $\mathrm{s} / \mathrm{g}$ wet weight) was not significantly different from that in the control fetus $(6.9 \pm 1.8)$ These data indicate that neither inotropic nor toxic effect (deterioration of mechanical function) of high $\left[\mathrm{Ca}^{2+}\right]_{o}$ can be explained by the high osmolarity per se.

Uncouplers of Excitation-Contraction. Figure $3 A$ shows the effect of $\mathrm{La}^{3+}$ on DT. $\mathrm{La}^{3+}$-induced decrease in DT was significantly $(p<0.05)$ less than in the control fetus. $\mathrm{La}^{3+}$ increased resting tension significantly in the control fetus, but not in FDM $(\mathrm{RT}=150 \pm 13 \%$ of control in normal fetus and $111 \pm 7 \%$ in FDM).

Effect of $\mathrm{Mn}^{2+}$ on DT is shown in Figure $3 B$. In FDM, the decrease in DT was not significantly different from that in the control fetus. $\mathrm{Mn}^{2+}$ increased resting tension similarly in the two age groups $(\mathrm{RT}=158 \pm 16 \%$ of control in normal fetus and 148 $\pm 10 \%$ in FDM).

Biochemical Study. Myofibrillar ATPase. The yield of myofibrillar protein in FDM $(27.8 \pm 2.1 \mathrm{mg} / \mathrm{g}$ muscle) was not significantly different from that in the control fetus $(28.9 \pm 1.0)$. In the myofibrillar fraction, cytochrome $c$ oxidase (mitochondrial marker) and $\left(\mathrm{Na}^{+}-\mathrm{K}^{+}\right)$-ATPase activities (sarcolemmal marker) were very low and were similar in the two groups.

Myofibrillar ATPase activity a function of $\mathrm{Ca}^{2+}$ concentration ( $\mathrm{pCa}=-\log [\mathrm{Ca}]$ ) is shown in Figure 4. There was no significant difference in the enzyme activities between the two age groups.

Mitochondrial $\mathrm{Ca}^{2+}$ uptake. The yield of mitochondrial protein 
Table 2. Baseline data of mechanical function*

\begin{tabular}{|c|c|c|c|c|c|c|}
\hline & $n$ & $\begin{array}{c}\text { DT } \\
\text { (g/g wet wt) }\end{array}$ & $\begin{array}{c}+\mathrm{dT} / \mathrm{dt} \\
(\max ) \\
(\mathrm{g} / \mathrm{s} / \mathrm{g} \text { wet } \mathrm{wt}) \\
\end{array}$ & $\begin{array}{c}\text { RT } \\
\text { (g/g wet wt) }\end{array}$ & $\begin{array}{l}\text { TPT } \\
\text { (ms) }\end{array}$ & $\begin{array}{c}1 / 2 \mathrm{RT} \\
\text { (ms) }\end{array}$ \\
\hline Control fetus & 33 & $8.6 \pm 0.5$ & $26.2 \pm 1.4$ & $2.8 \pm 0.1$ & $450 \pm 8$ & $354 \pm 11$ \\
\hline FDM & 35 & $9.8 \pm 0.8$ & $27.4 \pm 1.1$ & $2.7 \pm 0.1$ & $440 \pm 10$ & $350 \pm 8$ \\
\hline
\end{tabular}

* Values are means $\pm \mathrm{SE}$.

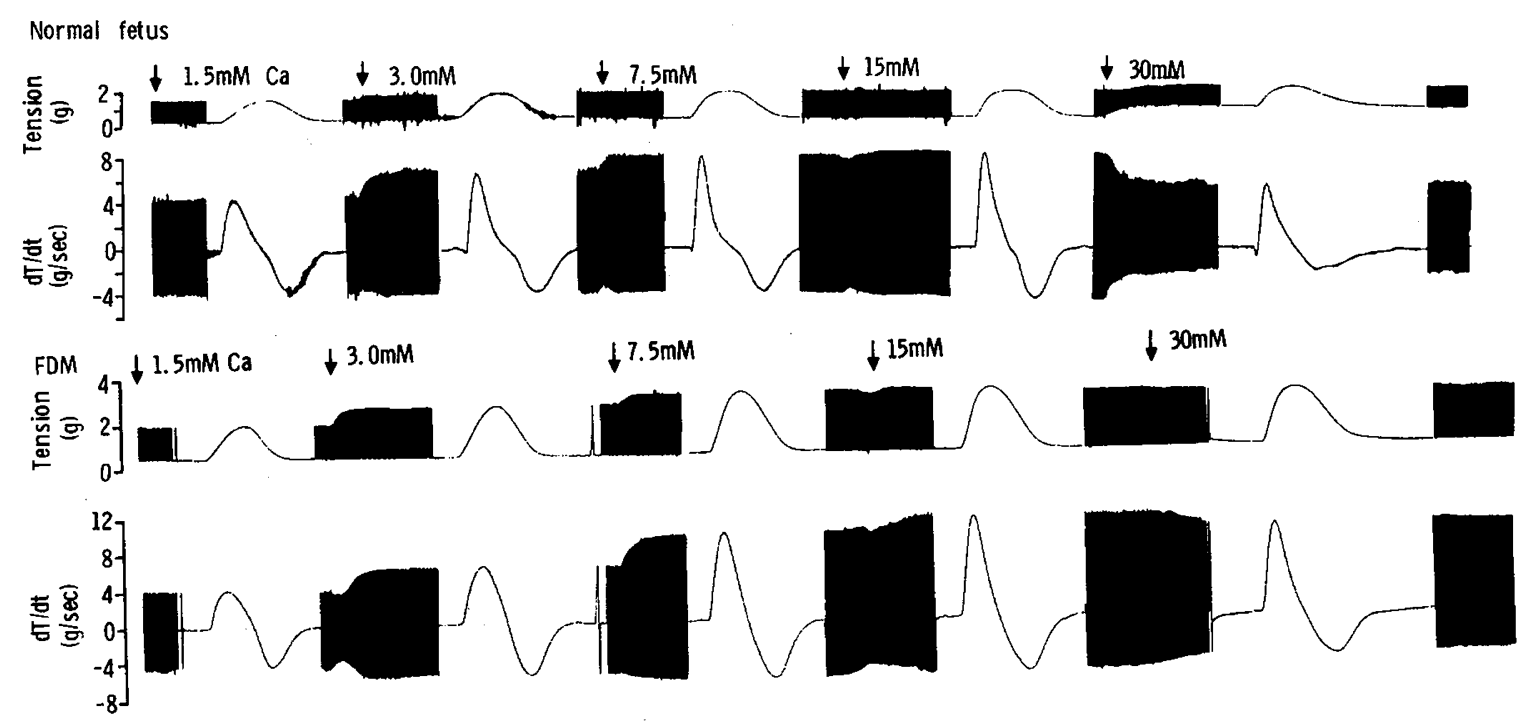

Fig. 1. Typical experiments that show the effect of $\left[\mathrm{Ca}^{2+}\right]_{0}$ on tension and first derivative of tension development (dT/dt). The inotropic effect of $\mathrm{Ca}^{2+}$ in FDM was greater than in the normal fetus.

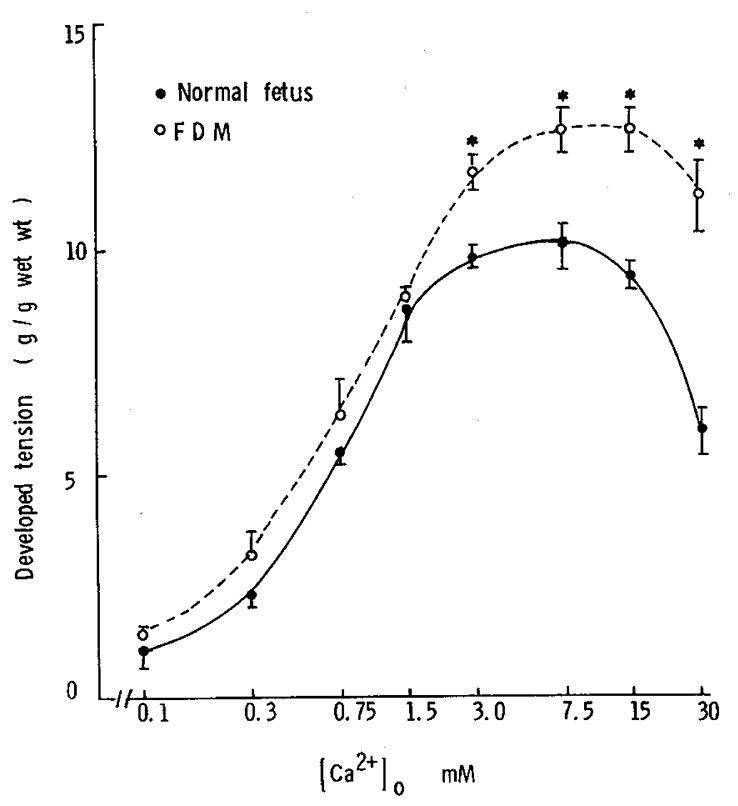

Fig. 2. Effect of $\left[\mathrm{Ca}^{2+}\right]_{o}$ on the DT per g muscle in FDM and normal fetus. *Significantly $(p<0.05)$ different from the value in the normal fetus.

in FDM $(4.8 \pm 0.3 \mathrm{mg} / \mathrm{g}$ muscle $)$ was not significantly different from that in the control $(4.4 \pm 0.3)$. In the mitochondrial fraction, sarcolemmal contamination estimated from $\left(\mathrm{Na}^{+}-\mathrm{K}^{+}\right)$-ATPase was minimal (less than $1 \%$ of the total activity) and it was similar in the two groups. In FDM, cytochrome $c$ oxidase activity in the mitochondrial fraction $(3.71 \pm 0.31 \mu \mathrm{mol} / \mathrm{mg}$ protein $/ \mathrm{min})$ was not significantly different from that in the control $(3.66 \pm 0.52)$, suggesting similar purity of mitochondrial fraction in the two groups. The rate of mitochondrial $\mathrm{Ca}^{2+}$ uptake was similar in the two groups (Table 3). $\mathrm{Mg}^{2+}$ inhibition of respiration-dependent $\mathrm{Ca}$ uptake was similar in the two groups.

$\mathrm{Ca}^{2+}$ uptake by sarcoplasmic reticulum. The yield of SR in FDM $(0.16 \pm 0.04 \mathrm{mg} / \mathrm{g}$ muscle) was not significantly different from that in the control fetus $(0.15 \pm 0.06)$. Cytochrome oxidase and $\left(\mathrm{Na}^{+}-\mathrm{K}^{+}\right)$-ATPase activities in SR fraction were very low (less than $1 \%$ of the total activities) and were similar in the two groups. SR Ca ${ }^{2+}$-ATPase activity in FDM $(143 \pm 18 \mathrm{nmol} / \mathrm{mg}$ protein $/ \mathrm{min}$ ) was similar to that in the normal fetus $(152 \pm 21)$. The rate of $\mathrm{Ca}^{2+}$ uptake by SR was also similar in the two groups (Table 3). The time course of $\mathrm{Ca}^{2+}$ uptake by SR from $15 \mathrm{~s}$ to 30 min was similar in the two groups.

\section{DISCUSSION}

The present study was designed to investigate myocardial mechanical function and the function of E-C coupling elements in FDM. In FDM, serum glucose and insulin levels were significantly greater than control values (Table 1). This finding is consistent with previous observations in human and animal FDM $(3,8)$. In the present study, body weight in FDM was not significantly greater than control (Table 1). The weight of the fetus of a severely diabetic mother is usually small while it is larger in the full term newborn of a mildly and moderately diabetic mother (3). This might explain the normal weight of the near term fetus of the moderately diabetic mother used in the present study. Under control conditions, mechanical function in FDM was similar to that in the normal fetus (Table 2). In order to delineate possible changes in E-C coupling in FDM, various interventions, which are known to alter $\mathrm{Ca}^{2+}$ availability to the E-C coupling elements, were used in the present study. Perfusion with high $\mathrm{Ca}^{2+}$ solution caused significantly greater inotropic effect in FDM than in the control fetus (Fig. 2). This may suggest that under control conditions the myocardial contractility reserve in FDM is greater than in the normal fetus. Contractile force is 

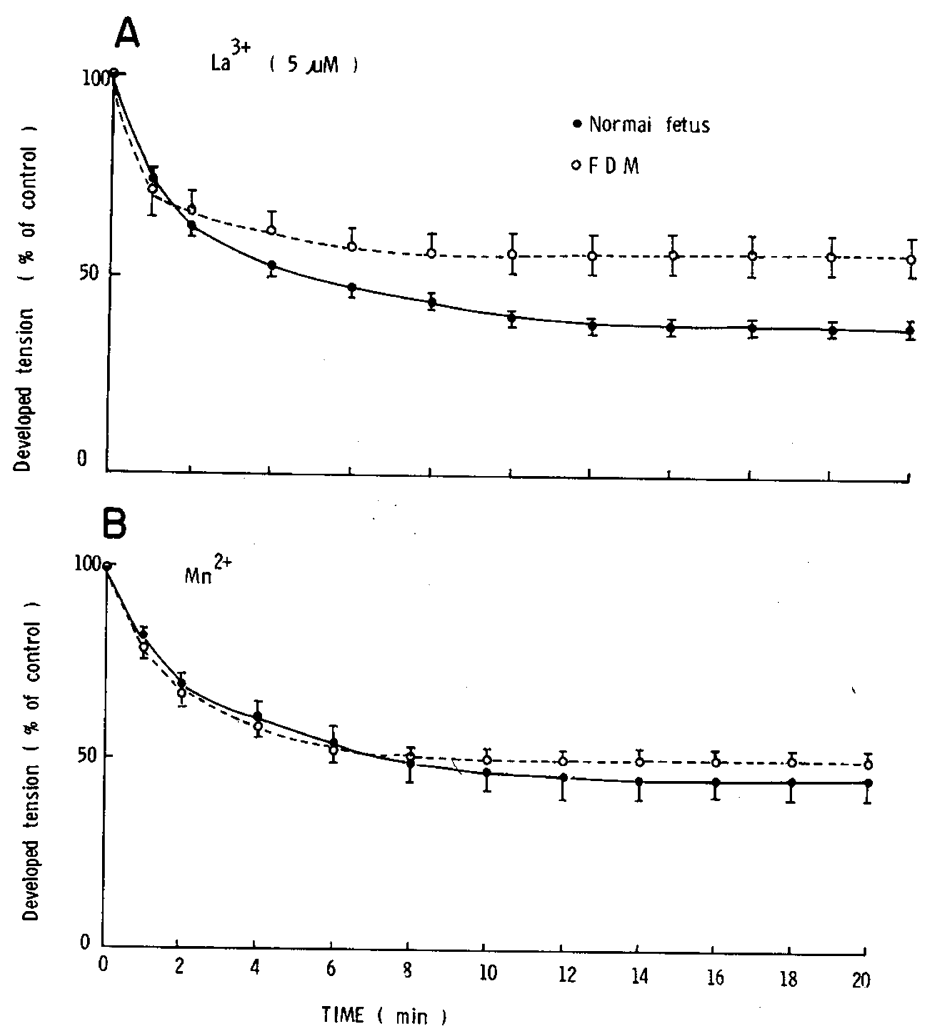

Fig. 3. $A$, effect of $\mathrm{La}^{3+}$ on DT. In FDM, the values in DT after 10 min of perfusion were significantly $(p<0.05)$ less than in the normal fetus. $B$, effect of $0.5 \mathrm{mM} \mathrm{Mn}{ }^{2+}$ infusion on DT. The decrease in DT was similar in the normal fetus and FDM.

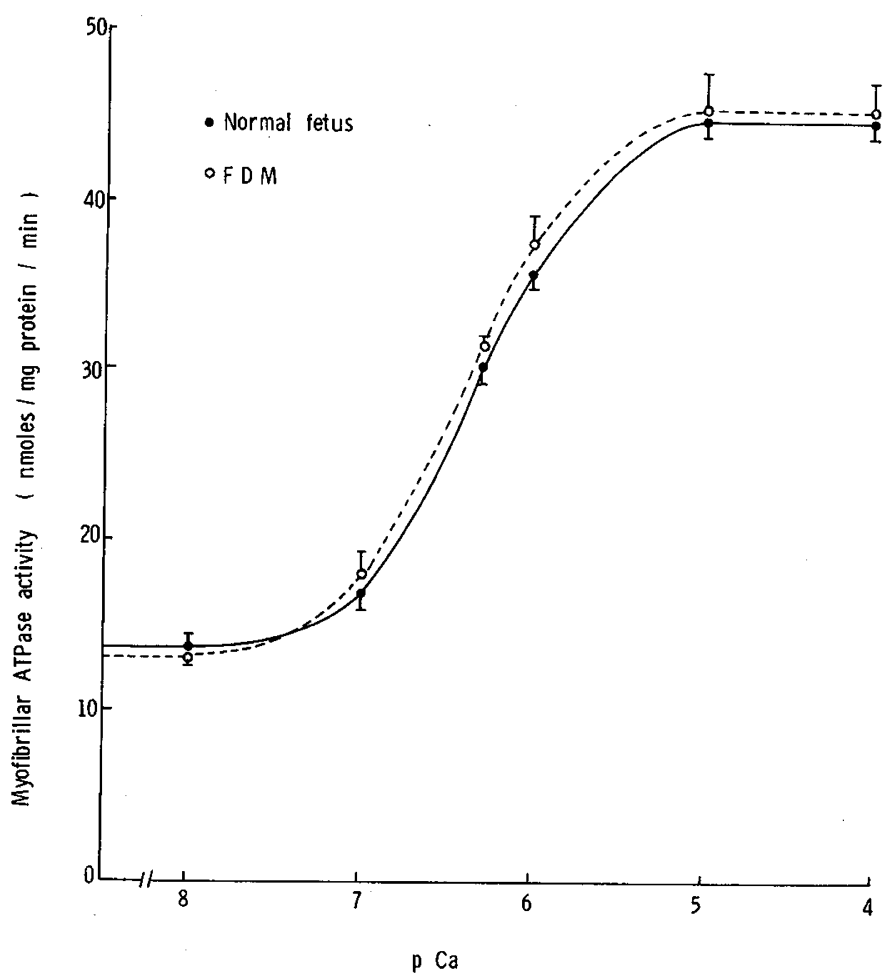

Fig. 4. Myofibrillar ATPase activity as a function of pCa (-log $\left.\left[\mathrm{Ca}^{2+}\right]\right)$. The enzyme activity was similar in the normal fetus and FDM.

largely determined by the amount of myofibrils and the amount of calcium reaching the myofilament (13). Because the myofibrillar content and ATPase activity were similar in the two groups, the greater contractile force in FDM may not be ex-
Table 3. Ca uptake by mitochondria and sarcoplasmic reticulum*

\begin{tabular}{cccc}
\hline & \multicolumn{2}{c}{$\begin{array}{c}\text { Mitochondria (nmol/ } \\
\text { mg protein/min) }\end{array}$} & $\begin{array}{c}\text { Sarcoplasmic } \\
\text { reticulum } \\
(\mathrm{nmol} / \mathrm{mg}\end{array}$ \\
\cline { 2 - 3 } & $-\mathrm{Mg}^{2+}$ & $\begin{array}{c}+\mathrm{Mg}^{2+} \\
(3.16 \mathrm{mM})\end{array}$ & protein/min $)$ \\
\hline $\begin{array}{c}\text { Control fetus } \\
(n=5)\end{array}$ & $350 \pm 15$ & $200 \pm 21$ & $226 \pm 19$ \\
FDM $(n=5)$ & $370 \pm 16$ & $189 \pm 10$ & $218 \pm 14$ \\
\hline
\end{tabular}

* Values are mean \pm SE. The composition of the reaction media is described in "Materials and Methods." The incubation time was $15 \mathrm{~s}$ to determine mitochondrial $\mathrm{Ca}$ uptake and $1 \mathrm{~min}$ to determine $\mathrm{Ca}$ uptake by the sarcoplasmic reticulum. Free $\mathrm{Ca}^{2+}$ concentration in the media was $10^{-5} \mathrm{M}$.

plained by the difference in the contractile protein. Although it is possible that myosin ATPase and its isoenzyme pattern in FDM are different from normal, we measured myofibrillar ATPase activity in the present study because this enzyme is important for physiological performance (25).

It may be argued that myocardial fiber disarray may exist in FDM and this resulted in the altered mechanical function. However, since myocardial fiber disarray would depress contractile force (26), it is difficult to explain the greater performance of the FDM heart in the present study. It is also difficult to explain the present findings by the differences in myocardial catecholamine content. Since both catecholamine and high [Ca $]_{o}$ raise intracellular calcium concentrations, catecholamine which might be driven out by the electrical stimulation would increase contractile force under control conditions but it does not increase the maximal contractile force obtainable at high $[\mathrm{Ca}]_{o}(18)$.

Experiments with excitation-contraction uncouplers were performed to investigate possible changes in $\mathrm{Ca}^{2+}$ metabolism associated with the sarcolemma and other intracellular organelles. $\mathrm{La}^{3+}$ was used as an extracellular uncoupler because $\mathrm{La}^{3+}$ displaces calcium from the sarcolemma and does not permeate the plasma membrane $(2,6)$. In the present study, the negative inotropic effect of $\mathrm{La}^{3+}$ in FDM was significantly less than in the control fetus (Fig. $3 B$ ). There are at least two explanations for this difference: 1) sarcolemma-bound $\mathrm{Ca}^{2+}$ in $\mathrm{FDM}$ is greater than in the control fetus, or 2) in $\mathrm{FDM} \mathrm{Ca}{ }^{2+}$ release from intracellular sites is greater than in the control fetus. $\mathrm{Mn}^{2+}$ was used as an intracellular uncoupler to determine the difference in $\mathrm{Ca}^{2+}$ availability from intracellular sites (19). George and Jarmakani (7) have shown that the negative inotropic effect of $\mathrm{Mn}^{2+}$ in the newborn rabbit was greater than in the adult. Because sarcoplasmic reticulum and T-tubules are underdeveloped in the newborn rabbit (compared to the adult; Ref. 20), it is likely that the $\mathrm{Mn}^{2+}$ study reflects $\mathrm{Ca}^{2+}$ availability; from the present study, the negative inotropic effect of $\mathrm{Mn}^{2+}$ was similar in the two groups (Fig. $3 B$ ). These data may suggest that $\mathrm{Ca}^{2+}$ release from intracellular sites is not different in the two groups and that sarcolemma-bound $\mathrm{Ca}^{2+}$ in FDM may be greater than in the control fetus. The fact that the initial rate of tension decline after $\mathrm{La}^{3+}$ infusion was similar in the two groups (Fig. $3 A$ ) may suggest that the sarcolemma-bound $\mathrm{Ca}^{2+}$ is different quantitatively, but not qualitatively.

Myocardial relaxation is dependent on the decay of cytosolic $\mathrm{Ca}^{2+}$ which occurs as a result of the translocation of $\mathrm{Ca}^{2+}$ by the sarcolemma, T-tubules, sarcoplasmic reticulum, and possibly mitochondria $(9,13)$. At $\left[\mathrm{Ca}^{2+}\right]$ o of 0.1 to $1.5 \mathrm{mM}$, myocardial relaxation parameters (resting tension and half-relaxation time) were similar in the two groups. To delineate possible differences in the capability of the $\mathrm{Ca}^{2+}$-sequestering system, parameters of myocardial relaxation were evaluated at high $\left[\mathrm{Ca}^{2+}\right]_{0}$. High

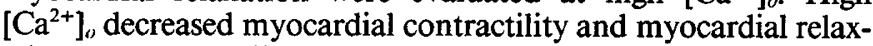
ation and these effects in FDM were less than in the control fetus. These data may suggest that the capability of the $\mathrm{Ca}^{2+}$ sequestering system in FDM is greater than in the control fetus. 
$\mathrm{Ca}^{2+}$ uptake by mitochondria and $\mathrm{SR}$ was studied to determine the capacity of intracellular organelles to regulate cytosolic $\mathrm{Ca}^{2+}$. The rate of $\mathrm{Ca}^{2+}$ uptake by mitochondria and SR in FDM was not different from that in the control fetus (Table 3). Therefore, it is difficult to explain the difference in relaxation parameters at high $\left[\mathrm{Ca}^{2+}\right]$, by the function of these intracellular organelles. It should be noted, however, that the yield of mitochondria and $\mathrm{SR}$ are indirect data to assess the content of these organelles. Although the present study shows that there are no qualitative changes in mitochondria and SR, additional quantitation of these organelles remains to be performed.

$\mathrm{La}^{3+}$ caused increases in RT in the control fetus, but not in FDM. Because $\mathrm{La}^{3+}$ does not permeate the sarcolemma, this $\mathrm{La}^{3+}$ effect might result from decreased $\mathrm{Ca}^{2+}$ efflux across the sarcolemma. These data may suggest that the ability of the sarcolemma to extrude intracellular $\mathrm{Ca}^{2+}$ is greater in FDM. The difference in the effects of high $\left[\mathrm{Ca}^{2+}\right]_{\text {o }}$ on $\mathrm{RT}$ and $1 / 2 \mathrm{RT}$ between the two groups may also be explained, at least in part, by the greater $\mathrm{Ca}^{2+}$ sequestration by the sarcolemma in FDM.

The mechanisms of the membrane alteration in diabetes mellitus are unclear but it is possible that hyperglycemia and hyperinsulinemia in FDM alter membrane lipid composition (12), amount of glycocalyx, and/or protein phosphorylation of the sarcolemma. Ultrastructural study of the sarcolemma and measurements of lipid composition, membrane-bound $\mathrm{Ca}^{2+}$, and $\mathrm{Na}^{+}-$ $\mathrm{Ca}^{2+}$ exchange using isolated sarcolemma should be performed to examine changes in the fetal sarcolemma induced by the maternal diabetes.

Since histological examination was not performed in the present study, it is uncertain whether FDM had hypertrophic cardiomyopathy. However, this possibility is unlikely because heart/ body weight ratios were similar in the two groups (Table 1). Furthermore, although this abnormality occurs only in 10-20\% of human infants of diabetic mothers $(8)$, the present study shows that mechanical function in all FDM is different from control. Nevertheless, it is possible that both hypertrophic cardiomyopathy noted clinically and the greater performance of the FDM heart demonstrated in the present study are related to the metabolic abnormalities (i.e., hyperinsulinemia and hyperglycemia) observed in FDM (3).

In conclusion, the present study indicates that the inotropic effect of calcium in FDM is greater than in the control fetus in the isolated heart preparation. We speculate that this difference may be due, at least in part, to a sarcolemmal alteration induced by the maternal diabetes.

Acknowledgment. The authors thank Mrs. Cathy Heteniak for editing and typing this manuscript.

\section{REFERENCES}

1. Angervall L 1963 Comparison between the actin on the fatal pancreatic isletes of alloxan injected to the pregnant rat to the fetuses in utero. Pathol Microbiol 26:412-417

2. Bers DM, Langer GA 1979 Uncoupling cation effects on cardiac contractility and sarcolemmal $\mathrm{Ca}^{2+}$ binding. Am J Physiol 237 (Heart Circ Physiol 6): $\mathrm{H} 332-\mathrm{H} 341$

3. Cuezva JM, Burkett ERS, Kerr DS, Rodman HM, Patel MS 1982 The newborn of diabetic rat. I. Hormonal and metabolic changes in the postnatal period. Pediatr Res 16:632-637

4. Fabiato A, Fabiato $F 1979$ Calculator programs for computing the composition of the solutions containing multiple metals and ligands used for experiments in skinned muscle cells. J Physiol (Paris) 75:463-505

5. Fiske CH, Subbarrow Y 1925 The colorimetric determination of phosphorus. J Biol Chem 66:375-440

6. Frank JS, Langer GA, Nudd LM, Seraydarian K 1977 The myocardial cell surface, its histochemistry, and the effect of sialic acid and calcium removal on its structure and cellular ionic exchange. Circ Res 41:702-714

7. George BL, Jarmakani JM 1983 The effects of lanthanum and manganese on excitation-contraction coupling in the newborn rabbit heart. Dev Pharmacol 6:33-44

8. Gutgesell HP, Speer ME, Rosenberg HS 1980 Characterization of the cardiomyopathy in infants of diabetic mothers. Circulation 61:441-450

9. Hoerter J, Mazet F, Vassort G 1981 Perinatal growth of the rabbit cardiac cell: possible implications for the mechanism of relaxation. J Mol Cell Cardiol 13:725-740

10. Jarmakani JM, Nakanishi T, George BL, Bers D 1982 Effect of extracellular calcium on myocardial mechanical function in the neonatal rabbit. Pharmacol 5:1-13

11. Jones LR, Besch JR, Fleming JW, McConnaughey MM, Watanabe AM 1979 Separation of vesicles of cardiac sarcolemma from vesicles of cardiac sarcoplasmic reticulum. J Biol Chem 254:530-539

12. Kasser TR, Marton RJ, Allen CE 1981 Effect of gestational alloxan diabetes and fasting on fetal lipogenesis and lipid deposition in pigs. Biol Neonate 40:105-112

13. Langer GA 1980 The role of calcium in the control of myocardial contractility: an update. J Mol Cell Cardiol 12:231-239

14. Lowry OH, Rosebrough NJ, Farr AL, Randall RJ 1951 Protein measurements with the Folin phenol reagent. J Biol Chem 193:265-275

15. Nakanishi T, Jarmakani JM 1981 The effect of acetyl strophanthidin on myocardial function and potassium and calcium exchange in the newborn rabbit. Am J Physiol 241 (Heart Circ Physiol 10):H637-H645

16. Nakanishi T, Jarmakani JM 1984 Developmental changes in myocardial mechanical function and subcellular organelles. Am J Physiol 246 (Heart Circ Physiol 15):H615-H625

17. Neufeld ND, Corbo LM, Kaplan SA 1981 Plasma membrane insulin receptors in fetal rabbit lung. Pediatr Res 15:1958-1962

18. Nishioka K, Nakanishi T, George BL, Jarmakani JM 1981 The effect of calcium on the inotrophy of catecholamine and paired electrical stimulation in the newborn and adult myocardium. J Mol Cell Cardiol 13:511-520

19. Ochi R 1970 The slow inward current and the action of manganese ions in guinea pigs myocardium. Pflugers Arch 316:81-94

20. Page E, Beucker JL 1981 Development of dyadic junctional complexes between sarcoplasmic reticulum and plasmalemma in rabbit left ventricular myocardial cells. Circ Res 48:519-522

21. Philipson KD, Nishimoto AY $1982 \mathrm{Na}^{+}-\mathrm{Ca}^{2+}$ exchange is affected by membrane potentials in cardiac sarcolemmal vesicles. $\mathrm{J}$ Biol Chem 255:68806882

22. Rhoades RA, Fillar DA, Vannata B 1979 Influence of maternal diabetes on lipid metabolism in neonatal rat lung. Biochim Biophys Acta 572:132-138

23. Singh M, Fiegelson M 1981 Effects of maternal diabetes on the development of carbohydrate metabolizing enzymes in fetal rat liver. Arch Biochem Biophys 209:655-667

24. Solaro RJ, Pang DC, Briggs FN 1971 The purification of cardiac myofibrils with Triton X-100. Biochim Biophys Acta 245:259-262

25. Solaro RJ, Wise RM, Shiner JS, Briggs FN 1974 Calcium requirements for cardiac myofibrillar activation. Circ Res 34:525-530

26. Urthaler F, Walker AA, Kawamura K, Hefner LL, James TN 1978 Canine atrial and ventricular muscle mechanics studied as a function of age. Circ Res 42:703-713

27. Wallenstein S, Zucker CL, Fleiss JL 1967 Some statistical methods useful in circulation research. Circ Res 47:1-9

28. Wharton CD, Tzagoloff A 1967 Cytochrome oxidase from beef heart mitochondria. Methods Enzymol 10:245-250 